\title{
Expression of E-selectin ligands on circulating tumor cells: cross-regulation with cancer stem cell regulatory pathways?
}

\section{Monica M. Burdick ${ }^{1,2 *}$, Karissa A. Henson ${ }^{2}$, Luis F. Delgadillo ${ }^{1}$, Young Eun Choi ${ }^{3}$, Douglas J. Goetz ${ }^{1,2}$, David F. J. Tees ${ }^{2,3}$ and Fabian Benencia ${ }^{2,4}$}

' Department of Chemical and Biomolecular Engineering, Russ College of Engineering and Technology, Ohio University, Athens, OH, USA

${ }^{2}$ Biomedical Engineering Program, Russ College of Engineering and Technology, Ohio University, Athens, OH, USA

${ }^{3}$ Department of Physics and Astronomy, College of Arts and Sciences, Ohio University, Athens, OH, USA

${ }^{4}$ Department of Biomedical Sciences, Heritage College of Osteopathic Medicine, Ohio University, Athens, OH, USA

\section{Edited by:}

Michael R. King, Cornell University, USA

\section{Reviewed by:}

Yue Geng, Cornell University, USA Gail M. Seigel, University at Buffalo, USA

\section{${ }^{*}$ Correspondence:}

Monica M. Burdick, Department of Chemical and Biomolecular Engineering, Russ College of Engineering and Technology, Ohio University, Stocker Center 171, Athens, OH 45701, USA. e-mail: burdick@ohio.edu
Although significant progress has been made in the fight against cancer, successful treatment strategies have yet to be developed to combat those tumors that have metastasized to distant organs. Poor characterization of the molecular mechanisms of cancer spread is a major impediment to designing predictive diagnostics and effective clinical interventions against late stage disease. In hematogenous metastasis, it is widely suspected that circulating tumor cells (CTCs) express specific adhesion molecules that actively initiate contact with the vascular endothelium lining the vessel walls of the target organ. This "tethering" is mediated by ligands expressed by CTCs that bind to E-selectin expressed by endothelial cells. However, it is currently unknown whether expression of functional E-selectin ligands on CTCs is related to cancer stem cell regulatory or maintenance pathways, particularly epithelial-to-mesenchymal transition and the reverse, mesenchymal-to-epithelial transition. In this hypothesis and theory article, we explore the potential roles of these mechanisms on the dynamic regulation of selectin ligands mediating CTC trafficking during metastasis.

Keywords: circulating tumor cells, cancer stem cells, epithelial-to-mesenchymal transition, selectins, selectin ligands, cell adhesion

\section{INTRODUCTION}

Distant metastasis is the culmination of an elaborate cascade of events in which cancer cells break away from the primary tumor, intravasate through blood vessel walls into the circulatory system, travel throughout the body, and finally extravasate through the vessels of a distant organ to establish a secondary colony. While resident in the blood vasculature, circulating tumor cells (CTCs) must survive biochemical and biophysical assaults inducing necrosis or apoptosis, plus avoid elimination by immune cells, in order to metastasize. Regardless of their ultimate fate, the clinical interpretation of CTCs arising from solid tumors has been the subject of much debate, with definitive answers yet to emerge as to if, when, and for which cancers these cells offer significant diagnostic, prognostic, or therapeutic value. Despite lack of consensus on their clinical utility, CTCs can still provide a meaningful portrait of a cancer patient's health, or rather disease, status. CellSearch, a test marketed by Johnson \& Johnson's Veridex division, is FDA-approved to capture and enumerate CTCs in metastatic breast, colon, and prostate cancer patients for prognostic purposes (Dawood et al., 2008; Mostert et al., 2009; Riethdorf and Pantel, 2010). More recently, the development of next-generation fluidics-based CTC isolation devices by the Haber and Toner groups, the CTC-chip and herringbone (HB)-chip (Nagrath et al., 2007; Stott et al., 2010; Yu et al., 2011), has generated increased attention to CTCs and the use of "liquid biopsies" or "blood biopsies" to enumerate and capture CTCs for further study.
As with any portrait, further examination reveals nuances not observed at first glance. For instance, post-capture investigation using RT-PCR in the AdnaTest (AdnaGen) may reveal upregulated pathways related to cancer stem cells (CSCs), metastatic aggressiveness, or responsiveness to treatment (i.e., trastuzumab for HER-2 overexpressing breast cancers) that are impossible to observe through a simple CTC count (Fehm et al., 2007; Dawood et al., 2008; Riethdorf and Pantel, 2008, 2010; Mostert et al., 2009). Though the scientific and medical communities may achieve significant new insights from these blood biopsies, the information itself is static. Cancer is dynamic. How medical professionals interpret a particular patient's case, as well as predict future outcomes of an ever-changing disease, will depend partially on information gleaned from CTC assessments at single moments in time.

In general, CTCs possessing enhanced survival capabilities will generate metastatic colonies in distant organs, as well as reseed the original primary tumor with more aggressive cells (Kim et al., 2009). Uncovering the molecular mediators by which CTCs initiate adhesion with endothelial cells lining the blood vessel walls of the target site may therefore prove useful in predicting and thwarting metastasis. In particular, stimulated vascular endothelium expressing E-selectin can capture CTCs expressing E-selectin ligands, thereby initiating adhesion and subsequent CTC invasion. However, this statement is a simplification of a tangle of issues underlying functional selectin ligand expression on cancer 
cells. To be qualified as a true selectin ligand, Varki (1997) proposed that the purported ligand must be expressed "in the right place at the right time" among other criteria. So do all CTCs express selectin ligands, or even the "right" selectin ligands? How and when do these selectin ligands arise? Are they modulated by pathways associated with epithelial-to-mesenchymal transition (EMT) or other mechanisms of CSC generation and maintenance, or are they independent of these pathways? In this article, we explore the complex networks through which selectin ligands on CTCs may be regulated and propose working theories based on ongoing studies with breast cancer in our laboratories. New findings from these investigations, coupled with additional discoveries from other labs, will address significant shortcomings in our understanding of the molecular networks promoting cancer metastasis.

\section{CTCS AND CELL ADHESION MEDIATED BY E-SELECTIN AND ITS LIGANDS}

It has been proposed that the early steps by which CTCs cells leave the bloodstream to invade secondary sites mimic the physiologic trafficking of leukocytes to sites of inflammation and hematopoietic stem cells to bone marrow. Because numerous excellent review articles on cell trafficking have been published through the years (Springer, 1994; Sackstein, 2005; Barthel et al., 2007; Konstantopoulos and Thomas, 2009; Zarbock et al., 2011; Bendas and Borsig, 2012; Chase et al., 2012; Geng et al., 2012), only a general overview is presented here (Figure 1). Circulating cells are first captured or "tethered" from bulk blood flow onto vascular endothelial cells, which is immediately followed by rolling on the endothelium. Tethering and rolling are typically mediated by interactions between ligands expressed on the surface of the circulating cells that recognize E-selectin, an endothelial adhesion molecule upregulated in response to inflammatory stimuli as well as constitutively expressed by bone and dermal endothelial cells (Springer, 1994; Sackstein, 2004). Subsequently, rolling cells firmly adhere and migrate through the vessel wall into the underlying tissue in response to specific cytokines and chemokines.
Therefore, this multi-step model indicates that CTCs must initially tether on endothelial cells, presumably through E-selectin ligand recognition of E-selectin, in order to trigger the series of events necessary for metastatic growth. These adhesive interactions occur under hydrodynamic shear stresses generated by blood flow (post-capillary venule and bone marrow endothelial venule wall shear stress ranges from 0.5 to $4.0 \mathrm{dyn} / \mathrm{cm}^{2}$; Jones et al., 1991; Mazo et al., 1998), enabled by the hallmark catch-slip bonds and rapid bond formation/breakage kinetics of selectins and their ligands (Dembo et al., 1988; Marshall et al., 2003; Zhu and McEver, 2005; Evans and Calderwood, 2007; Ham et al., 2007; McEver and Zhu, 2007). E-selectin has been established as a mediator of colon and prostate cancer adhesion and distant metastasis (Khatib et al., 2002; Barthel et al., 2007, 2009), and there is clinical and in vitro evidence for the role of E-selectin in promoting metastasis of several other cancers, including breast, pancreatic, and head and neck cancers (Wenzel et al., 1995; Eshel et al., 2000; Barthel et al., 2007; Geng et al., 2012). The other two members of the selectin family, P-selectin expressed by activated platelets and activated endothelium and L-selectin expressed by most leukocytes, also have been proposed to participate in cancer metastasis (Laubli and Borsig, 2010; St Hill, 2012).

Notably, the expression levels of the minimal selectin-binding epitopes sialyl Lewis X (sLe ${ }^{X}, \operatorname{NeuAc} \alpha(2,3) \operatorname{Gal} \beta(1,4)[\operatorname{Fuc} \alpha(1,3)]$ GlcNAc) and its stereoisomer sialyl Lewis A ( $\operatorname{sLe}^{\mathrm{A}}, \mathrm{NeuAc \alpha}(2,3)$ $\operatorname{Gal} \beta(1,3)[\operatorname{Fuc} \alpha(1,4)]$ GlcNAc) on certain glycoproteins and glycolipids increase progressively from normal tissue to early stage cancer to metastatic disease, consistent with aberrant glycosylation rendering altered cell adhesion molecules relative to normal tissue in most cancers, including breast, bladder, and colon cancers (Izumi etal., 1995; Klopocki et al., 1996; Renkonen et al., 1997; Skorstengaard et al., 1999; Kajiwara et al., 2005). Transfer of sialic acid (NeuAc) onto a terminal galactose $(\mathrm{Gal})$ residue occurs through the action of $\alpha(2,3)$ sialyltransferases. The enzymes directing $\alpha(1,3)$ fucosylation for sLe ${ }^{\mathrm{X}}$ production are multiplefucosyltransferases (FTs) III, IV, V, VI, and VII while FTIII and FTV are also $\alpha(1,4)$ FTs involved in the production of sLe $^{\mathrm{A}}$ (Edbrooke et al., 1997; de Vries et al., 2001; Dupuy et al., 2004).

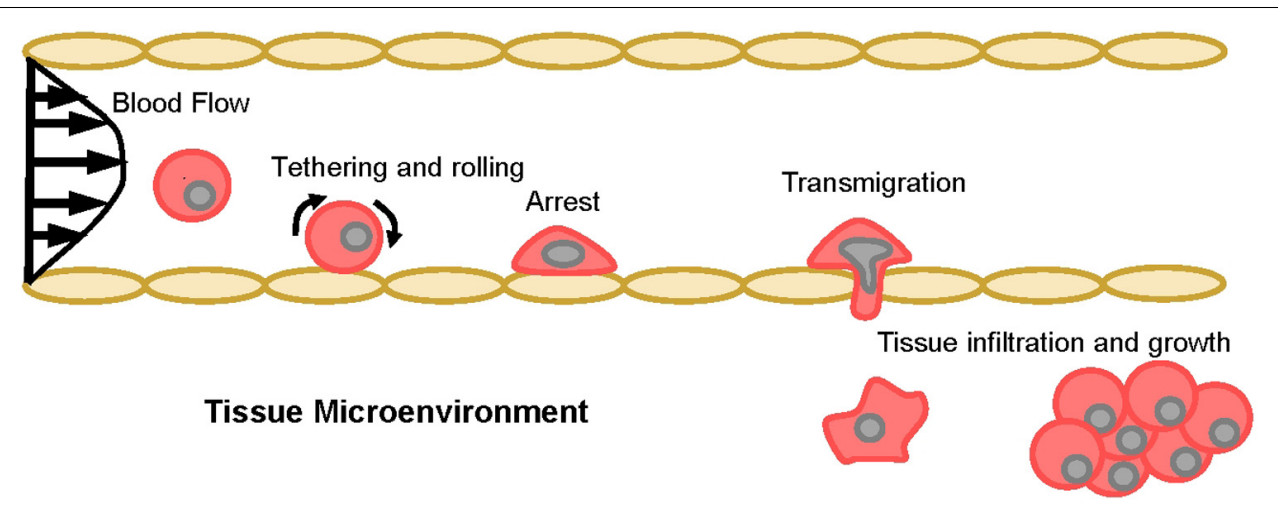

FIGURE 1 | The multi-step model of cell adhesion and migration in blood vessels. Schematic representation of the cascade of events involved in cellular transit from the vasculature into the underlying tissue space. Tethering recruits circulating cells from the bulk flow stream, then rolling slows lateral translocation across the endothelium and facilitates firm arrest. If the correct cytokine and/or chemokine gradients are present, adherent cells will transmigrate through the endothelium and infiltrate the tissue microenvironment. 
Clearly, these enzymes must be (dys)regulated in cancer cells through the transition from primary tumor to advanced stage cancer to result in the observed upregulation of $s \mathrm{Le}^{\mathrm{X} / \mathrm{A}}$ and thus selectin ligands (Renkonen et al., 1997; Matsuura et al., 1998). Although the tumor stroma and hypoxic conditions are known to influence tumor cell glycosylation (Stern et al., 2001, 2002; Kannagi, 2004), the exact biochemical (or biophysical) regulators of cancer glycosylation are unknown. Nevertheless, the presence of sialofucosylated moieties such as sLe $\mathrm{X}^{\mathrm{A}}$ is significant in that upregulated expression of functional selectin ligands may indicate their role in promoting CTC adhesion during metastasis (Burdick et al., 2001; Kannagi et al., 2004; Barthel et al., 2007). Thus, it is necessary to identify the core proteins or lipids presenting sialofucosylated glycans to better characterize roles for specific selectin ligands.

To date, several major tumor cell surface glycoprotein selectin ligands that may fulfill the criteria of "real" selectin ligands have been identified, most prominently the specialized CD44 glycoform HCELL as an E-/L-/P-selectin ligand on colon cancer cells (Hanley et al., 2005, 2006; Burdick et al., 2006), and an E-selectin ligand on prostate and breast cancer cells (Barthel et al., 2009; manuscript in preparation). Carcinoembryonic antigen (CEA, CD66) and podocalyxin-type protein-1 (PCLP-1) have also been named E-selectin ligands expressed on colon and prostate cancer cells (Barthel et al., 2009; Thomas et al., 2009). On breast cancer cells, CD24 acts as a P-selectin ligand but not an E-selectin ligand (Aigner et al., 1998), and Mac-2bp acts as an E-selectin ligand (Shirure et al., 2012). Additional mucinous proteins, such as MUC-1, CD43, and PSGL-1, have also been proposed as selectin ligands on a variety of cancer cells (Barthel et al., 2007; Geng et al., 2012). Contributory roles have also been identified for colon, prostate, breast, and head and neck cancer sialofucosylated glycolipids in adhesion to endothelial E-selectin (Burdick et al., 2003; Dimitroff et al., 2004; Barthel et al., 2007; Shirure et al., 2011; Geng et al., 2012). Though the understanding of selectins and their ligands is growing, it is imperative to consider their functionalities in the wider context of biochemical and biophysical factors encountered by CTCs in transit.

\section{CTC TRANSIT THROUGH CAPILLARIES}

The ability of cancer cells to enter small vessels such as capillaries (as well as to roll in larger vessels such as post-capillary venules described above) depends critically on the mechanical deformability of the cells. Capillaries range from 2 to $8 \mu \mathrm{m}$ in diameter (Doerschuk et al., 1993) and cancer cells, which tend to be large and stiff, may not be able to deform enough to enter at least some portions of the capillary bed (Liotta, 1987; Weiss et al., 1988; Chambers et al., 1992; Lafrenie et al., 1993). Organs with small vessels that are susceptible to metastasis include the lung microcirculation (which is particularly important because it is the first capillary bed that a metastasizing cancer cell entering the venous circulation will encounter after passing through the first two chambers of the heart), bone marrow and liver sinusoids, and the kidney microcirculation. The mechanical properties of cancer cells surely play a role in transit: if certain CTCs are stiff and resistant to deformation, then the possibility of sequestration at the entrance of small vessels should be large.
Conversely, if CTCs are less stiff (more deformable), then their potential to pass through the microcirculation and metastasize could be enhanced. Furthermore, it is possible that deformation is not a by-stander process for the cell; deformation itself may induce changes affecting molecular and mechanical phenotype, perhaps in a manner that promotes CTC survival and metastasis.

Protocols to quantify cellular mechanical properties have existed for nearly 30 years, and parameters for models of cell mechanics have been measured using many experimental techniques: micropipette aspiration (Figure 2), magnetic twisting rheometry, cell stretching with optical tweezers or mechanical stretching devices, nanoscale indentation with probes or AFM tips, particle tracking microrheology, etc. (Mason and Weitz, 1995; Shroff et al., 1995; Choquet et al., 1997; Mason et al., 1997; Thoumine and Ott, 1997; Bausch et al., 1999; Yap and Kamm, 2005; Sirghi et al., 2006). As a result of these efforts, much is known about the deformability of red and white blood cells (which are known to undergo massive deformations in the normal course of circulation) and a sampling of other cell types. On the basis of these collective works (Mason and Weitz, 1995; Shroff et al., 1995; Choquet et al., 1997; Mason et al., 1997; Thoumine and Ott, 1997; Bausch et al., 1999; Yap and Kamm, 2005; Sirghi et al., 2006), it was found that the major distinction in cell rheological properties is whether the cell behaves like a liquid drop with a cortical tension (as white blood cells clearly do) or as a viscoelastic solid (most other cell types). Devices to identify cell subsets based on differences in cellular mechanical properties are in early development stages (Oakey etal., 2010; Sraj et al., 2010), and these methodologies are being considered for identifying and isolating normal healthy mesenchymal stem cells (MSCs) for use as therapeutics and in regenerative medicine (Porada et al., 2006; Parekkadan and Milwid, 2010). These cells lack unique cell surface molecules through which they can be easily isolated from their sources (e.g., bone marrow, umbilical cord; Porada et al., 2006; Pountos et al., 2007) but have distinct mechanical properties compared to their
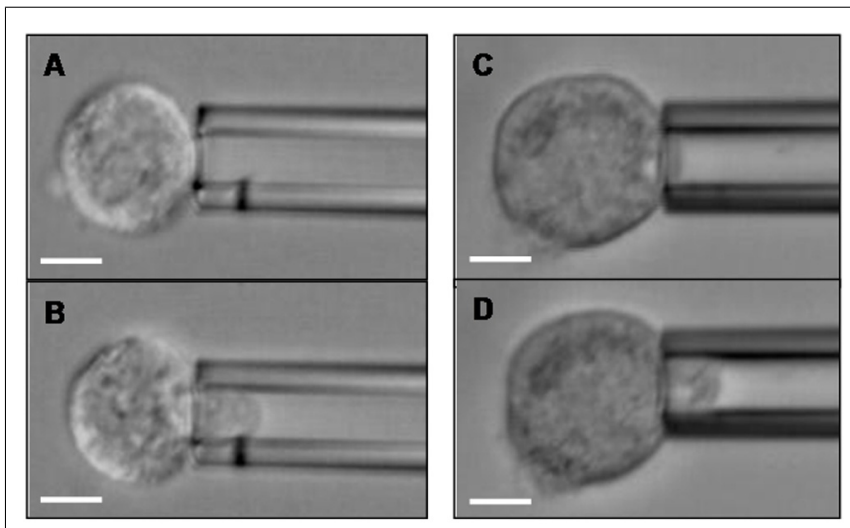

FIGURE 2 | Breast cancer cells can be aspirated into a glass micropipette. A CD44+/CD24- Hs578T breast cancer cell (A) before and (B) after partial aspiration into a micropipette of $8.4 \mu \mathrm{m}$ diameter. A CD $44^{+} / \mathrm{CD} 24^{+}$BT-20 breast cancer cell (C) before and (D) after partial aspiration into a $9.0 \mu \mathrm{m}$ diameter micropipette. Scale bar is $10 \mu \mathrm{m}$ in all Figures. 
differentiated daughter cells. These differences are currently being explored as specific identifying MSC characteristics (Darling et al., 2008; Tan et al., 2008; Yu et al., 2010). Similarly, benign versus tumorigenic cancer cells have been explored for differing traits (Kim et al., 2008; Hou et al., 2010). However, much more work needs to be performed to understand CTC metastatic potential attributable to inherent or alterable molecular and mechanical properties. It is tantalizing to speculate a role for biophysical modulation of CTC properties, including effects on selectin ligand expression or function.

\section{CSCs, EMT, AND MESENCHYMAL-TO-EPITHELIAL TRANSITION}

The discovery and identification of leukemic stem cells (LSCs) effectively ushered in a new era of cancer research (Lapidot et al., 1994; Bonnet and Dick, 1997). LSCs share the properties of selfrenewal and pluripotency with their normal hematopoietic stem cell brethren, but are also leukemogenic. LSCs are particularly dangerous in that they can survive chemotherapy (Costello et al., 2000; Graham et al., 2002; Holtz et al., 2002), leading to relapse with LSCs even more aggressive than their previous incarnation (Oravecz-Wilson et al., 2009). Shortly after LSC identification, a groundbreaking report by Al-Hajj et al. (2003) found that breast cancers similarly harbor deadly CSCs, which exhibited a much greater propensity for tumor formation than cells of a different phenotype. These breast CSCs were putatively characterized by the expression levels of glycoprotein markers on the surface of the cell: high expression of CD44, little to no expression of CD24, high expression of epithelial-specific antigen (ESA), and lack of lineage markers (lin), or $\mathrm{CD} 44^{+} / \mathrm{CD} 24^{- \text {low }} / \mathrm{ESA}^{+} / \mathrm{lin}^{-}$ (Al-Hajj et al., 2003). These CSCs were able to form heterogeneous tumors from a relatively small number of cells. Specifically, only $200 \mathrm{CD} 44^{+} / \mathrm{CD} 24^{-/ \text {low }} / \mathrm{ESA}^{+} / \mathrm{lin}^{-}$breast cancer cells, isolated from patient primary tumors, could regenerate and expand to form secondary tumors that also contained CSCs, in as little as 12 weeks in mice (Al-Hajj et al., 2003). In contrast, as many as 20,000 cells of alternate phenotypes from the same tumor origin as the $\mathrm{CD} 44^{+} / \mathrm{CD} 24^{- \text {llow }} / \mathrm{ESA}^{+} / \mathrm{lin}^{-}$cells were unable to form new tumors. Thus, the breast CSCs were capable of selfrenewal and differentiation, two general properties possessed by normal stem cells, and the ability to generate new tumors (Al-Hajj et al., 2003; Ponti et al., 2005; Fillmore and Kuperwasser, 2008). Since this initial breast cancer study, CSCs have reportedly been found in nearly all solid cancers, with a specific molecular phenotype for each type of cancer. However, the cancer research community continues to debate the true nature of CSCs (Campbell and Polyak, 2007; Gupta et al., 2009; Badve and Nakshatri, 2012; Liu etal., 2012; Magee et al., 2012), including whether CSCs are tumor-initiating or metastasis-initiating cells (Kelly et al., 2007; Adams and Strasser, 2008; Fillmore and Kuperwasser, 2008). The reasons for the extended scientific discussion are many and are outlined in a comprehensive review from the Morrison lab (Magee et al., 2012).

Perhaps some of the confusion and seemingly contradictory findings surrounding CSCs will be allayed by the growing evidence demonstrating that CSCs are not a single population of cells identified by one specific molecular signature. Rather, while all
CSCs possess general stem cell properties, CSCs are actually comprised of heterogeneous subpopulations with multiple molecular and functional phenotypes that are generated through different pathways (Liu etal., 2012; Magee et al., 2012). It is becoming abundantly clear for breast cancer that such heterogeneity exists in its CSCs. Breast CSCs that are CD $44^{+} / \mathrm{CD} 24^{-}$(the simplified breast CSC phenotype) are the result of cytokine-induced EMT (Mani et al., 2008; Morel et al., 2008; Blick et al., 2010; Liu et al., 2012), a process by which cells lose epithelial characteristics (E-cadherin expression, cell-cell contacts, polarity) and become more mesenchymal (N-cadherin expression, mesenchymal morphology, enhanced migration abilities; Onder et al., 2008; Zeisberg and Neilson, 2009). Many of the properties EMT confers are normally helpful to development (Kalluri and Weinberg, 2009), but EMT can also contribute to cancer progression in adult tissue (Mani et al., 2008; Onder et al., 2008). Often, cancer cells at the invasive front of a primary tumor have a mesenchymal phenotype (Kalluri and Weinberg, 2009). Interestingly, in breast cancer patients with metastases, CTCs have been found to express markers of EMT in addition to stem cell traits (Aktas et al., 2009; Bonnomet et al., 2010; Kallergi et al., 2011). It is important to note that EMT is reversible, such that cells can undergo mesenchymalto-epithelial transition (MET). The Wicha group reported that CSCs can exist in an MET state (Liu et al., 2012) as well as an EMT state previously found by the Weinberg group (Mani et al., 2008; Liu et al., 2012). MET CSCs actively self-renew and express aldehyde dehydrogenase (ALDH, a marker independently identified as a CSC indicator in several types of cancer (Ginestier et al., 2007; Clay et al., 2010; Silva et al., 2011; Kryczek et al., 2012), epithelial cell adhesion molecule (EpCAM, the same molecule that forms the basis for the capture of CTCs by CellSearch and the CTCand HB-chips), and CD49f ( $\alpha_{6}$ integrin subunit) in contrast to quiescent yet invasive $\mathrm{CD} 44^{+} / \mathrm{CD} 24^{-} / \mathrm{EpCAM}^{-} / \mathrm{CD}_{49 f^{+}} \mathrm{EMT}^{-}$ CSCs (Liu et al., 2012). Given the interconversions between CSC states, which are regulated by microRNAs (miRNAs), it is not surprising that there exists a subpopulation of $\mathrm{CD} 44^{+} / \mathrm{CD} 24^{-}$ and $\mathrm{ALDH}^{+}$cells (Liu et al., 2012). However, studies linking CSCs with properties facilitating CTC lodgment at sites of metastasis (i.e., selectin ligands and cell mechanical properties) are lacking.

\section{PUTTING IT ALL TOGETHER: HYPOTHESIZED BREAST CANCER MODELS LINIIING REGULATION OF CSCs, CTCS, AND E-SELECTIN LIGANDS}

Arguably, CSCs and CTCs from breast cancer are the most well-studied among all cancers, thereby easing efforts aimed at uncovering crosstalk between CSC regulatory pathways, CTC characteristics, and expression of functional selectin ligands. Such investigations may aid in diagnosing breast cancer at an early stage, when it is largely considered curable, or assist in identifying new therapeutic targets or treatment modalities for those women diagnosed at the metastatic stage, for whom the 5-year survival rate is $\sim 20 \%$ (DeSantis et al., 2011). Most commonly, breast cancer metastases are found in the lungs and bone marrow (Moore, 2001; Minn et al., 2005; Balic et al., 2006; Riethdorf and Pantel, 2010), exhibiting a tropism not explainable by circulation pattern alone (Minn et al., 2005; Talmadge and Fidler, 
2010). Recently, it has been reported that disseminated breast cancer cells in human bone marrow are largely CD44 ${ }^{+} / \mathrm{CD} 24^{-}$ (Abraham et al., 2005; Balic et al., 2006), corresponding to EMT CSCs. These CD $44^{+} / \mathrm{CD} 24^{-}$are also resistant to radiotherapy and chemotherapy (Diehn and Clarke, 2006; Phillips et al., 2006; Reim et al., 2009). It is therefore necessary to understand the reasons for $\mathrm{CD} 44^{+} / \mathrm{CD} 24^{-}$breast cancer cells in bone: whether CTCs are $\mathrm{CD} 44^{+} / \mathrm{CD} 24^{-} \mathrm{CSC}$ that preferentially migrate and establish metastases, or if non-CD $44^{+} / \mathrm{CD} 24^{-}$CTCs are induced to the CD $44^{+} / \mathrm{CD} 24^{-}$phenotype in the bone marrow.

As mentioned previously, E-selectin is constitutively expressed on bone marrow endothelium (Keelan et al., 1994; Schweitzer et al., 1996), and breast cancer cells have been shown to express E-selectin ligands on their surface (Tozeren et al., 1995; Narita et al., 1996; Zen et al., 2008; Julien et al., 2011; Shirure et al., 2011, 2012). Previous studies have also demonstrated the E-selectindependence of binding interactions between commercially available breast cancer cell lines and human umbilical vein endothelial cells (HUVECs; Giavazzi et al., 1993; Narita et al., 1996; Julien et al., 2011; Shirure et al., 2011, 2012). As the expression levels of the minimal selectin-binding epitopes sLe $\mathrm{X}^{\mathrm{X}}$ and $\mathrm{sLe}^{\mathrm{A}}$ increase progressively from normal tissue to early stage breast cancer to metastatic disease (Renkonen et al., 1997), it may be hypothesized that CTCs retain expression of selectin ligands that were generated in the primary site, then upregulate such ligands during transit to the metastatic site. Altogether, these findings imply that E-selectin and its ligands are likely to comprise important elements of breast cancer metastasis in vivo. Since breast cancer cells at the invasive front of a primary tumor tend to be mesenchymal (Kalluri and Weinberg, 2009) and breast CTCs have been found to express markers of EMT in addition to stem cell traits (Aktas et al., 2009; Bonnomet et al., 2010), it would seem a logical extension of the hypothesis that E-selectin ligands are upregulated with EMT and the corresponding CD $44^{+} / \mathrm{CD} 24^{-}$CSC phenotype. However, our studies with human breast cancer cell lines revealed surprising results: non-CD $44^{+} / \mathrm{CD} 24^{-}$cells expressed much greater E-selectin ligand activity than $\mathrm{CD} 44^{+} / \mathrm{CD} 24^{-}$cells (Figure 3 and Table 1; Shirure et al., 2011, 2012; manuscript in preparation). These findings imply that lower expression of E-selectin ligands correlates with $\mathrm{CD} 44^{+} / \mathrm{CD} 24^{-}$breast CSCs arising from EMT. Notably, the bone marrow microenvironment is enriched in TGF- $\beta$, a cytokine that is well-known to induce EMT (Brown et al., 2004; Lee et al., 2008; Mani et al., 2008; Lenferink et al., 2010), and production of TGF- $\beta$ by microenvironment stromal cells may be responsible for $\mathrm{CD} 44^{+} / \mathrm{CD} 24^{-}$breast cancer cells in bone (Abraham et al., 2005; Balic et al., 2006). Thus, it may be speculated that soluble TGF- $\beta$ decreases the expression of E-selectin ligands either before or during CTC engagement with bone marrow endothelium (Figure 4), thus throwing into doubt the relevance of E-selectin ligands on breast CTCs in establishing bone metastases. Studies in which EMT is induced in breast cancer cells need to be performed, with coordinated monitoring of glycosylation machinery, core E-selectin ligand protein and lipid expression, E-selectin ligand activity under flow conditions, and EMT and CSC markers, in order to verify or refute mechanistic links between functional E-selectin ligand expression and transition/maintenance of $\mathrm{CD} 44^{+} / \mathrm{CD} 24^{-}$CSCs. Ultimately, it may be found that downregulation of E-selectin ligands is not dependent on EMT per se, since E-selectin ligand activity fails to decrease consistently from the least mesenchymal luminal to the

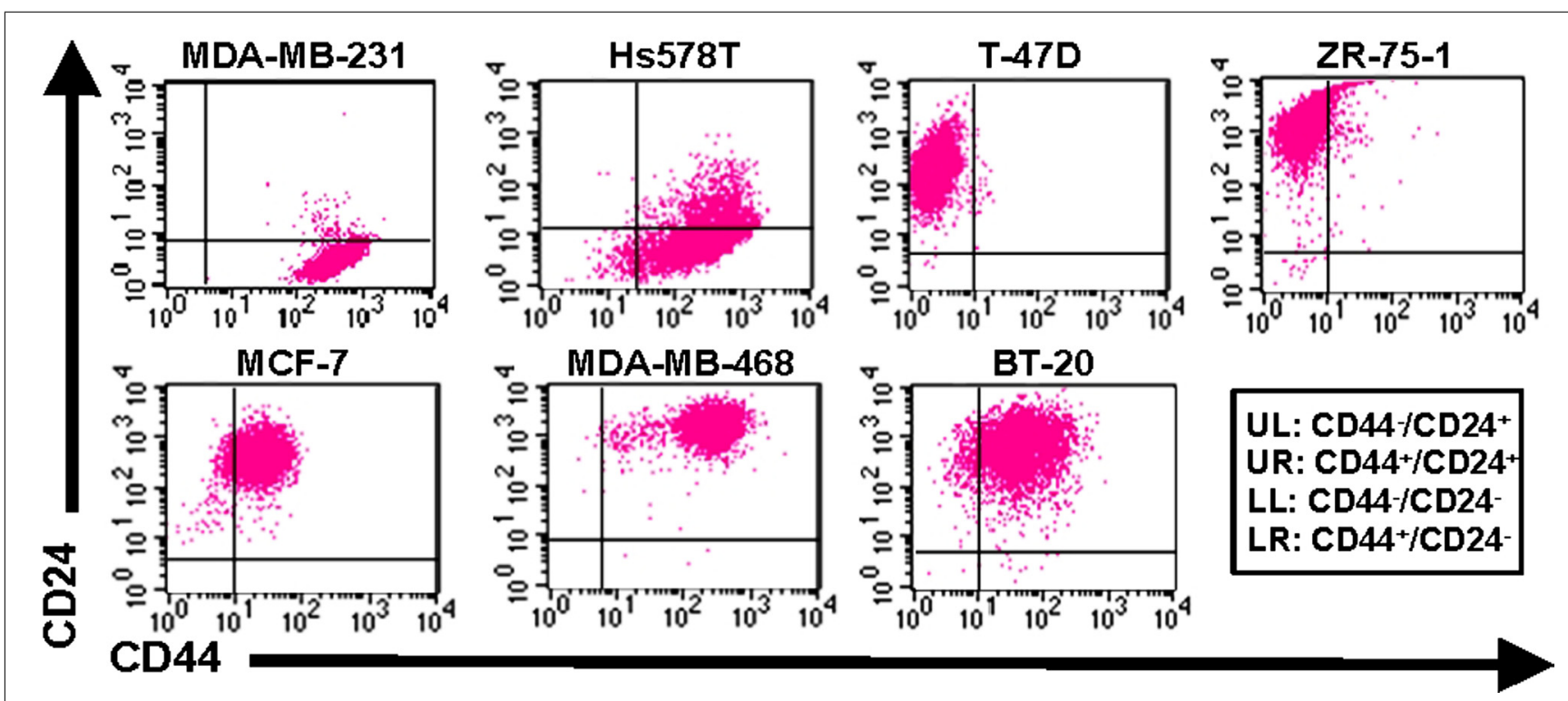

FIGURE 3 | Expression of CD44 and CD24 on breast cancer cell lines. Flow cytometric analysis of cell surface expression on human breast cancer cells from the American Type Culture Collection (ATCC). Cells were simultaneously stained with CD44-FITC and CD24-PE mAbs and analyzed on a BD FACSort cytometer/sorter. Quadrants were set using appropriate FITC or
PE-labeled isotype controls. The upper left quadrant represents CD44-/CD24+ cells, upper right quadrant represents CD24+/CD24+, the lower right quadrant represents $\mathrm{CD} 44^{+} / \mathrm{CD} 24^{-}$cells (i.e., phenotype of purported breast cancer stem cells), and lower left quadrant represents $\mathrm{CD}_{4}{ }^{-} / \mathrm{CD}^{2} 4^{-}$. Data are representative of $n=6$ independent experiments. 


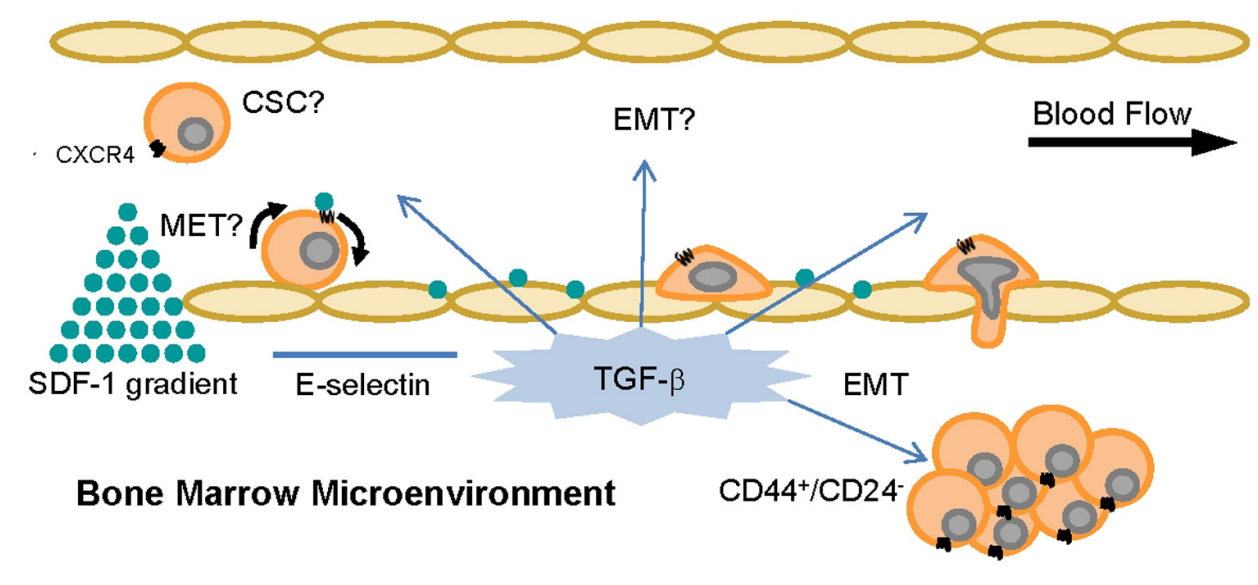

FIGURE 4 |TGF- $\beta$ and SDF-1 can alter CTC phenotype and behavior in the bone. The cytokine TGF- $\beta$ and the chemokine SDF-1 are constitutively expressed in the bone microenvironment and control pathways related to cell adhesion and homing, EMT, MET, cell cycle, and tumorigenicity. It is currently unknown if inducible EMT or MET affects cancer cell expression of functional E-selectin ligands and thus CTC capacity to metastasize. somewhat mesenchymal basal A to the most mesenchymal basal B cells (Table 1). Instead, persistent suppression of E-selectin ligands in $\mathrm{CD} 44^{+} / \mathrm{CD} 24^{-}$CSCs may be controlled by EMT pathways.

Alternatively, the MET state of CSCs (indicated by ALDH expression but not necessarily CD $44^{+} / \mathrm{CD} 24^{-}$cells; Liu et al., 2012) may regulate E-selectin ligand expression or function. Interestingly, a recent study of all cell lines in Table 1 except Hs578T revealed that BT-20 and MDA-MB-468 cells, both $\mathrm{CD} 44^{+} / \mathrm{CD} 24^{+}$ cell lines of the basal A type with relatively high E-selectin ligand

Table 1 | Expression of CD44, CD24, and E-selectin ligands on human breast cancer cell lines.

\begin{tabular}{llll}
\hline Cell line & $\begin{array}{l}\text { CD44/CD24 } \\
\text { status }\end{array}$ & Subtype & $\begin{array}{l}\text { E-selectin ligand } \\
\text { activity }\end{array}$ \\
\hline MDA-MB-231 & + /low & Basal B & + \\
Hs578T & $+/$ low & Basal B & + \\
ZR-75-1 & low/ & Luminal & +++ \\
T-47D & low/t & Luminal & ++ \\
MCF-7 & $+/+$ & Luminal & +++ \\
MDA-MB-468 & $+/+$ & Basal A & +++ \\
BT-20 & $+/+$ & Basal A & ++++ \\
\hline
\end{tabular}

Column 1: Human breast cancer cell lines from ATCC. Column 2: Flow cytometric analysis of cell surface expression on breast cancer cells. Key: - is $<2 \%$ positive (i.e., same intensity as isotype control antibody), low is $2-10 \%$ positive, moderate is $10-80 \%$ positive, + is $>80 \%$ positive. Column 3: Breast cancer cell subtype as reported by Neve et al. (2006). Column 4: E-selectin ligand activity was assessed in the parallel plate flow chamber (Shirure etal., 2011, 2012; and manuscript in preparation). Key: +, upper limit of E-selectin-dependent tethering (i.e., recruitment from fluid flow) to IL-13-stimulated HUVECs typically observed at wall shear stress of $0.5 \mathrm{dyn} / \mathrm{cm}^{2}$, beyond which no tethering was observed; ++, upper limit of tethering observed at wall shear stress of $0.8 \mathrm{dyn} / \mathrm{cm}^{2} ;+++$, upper limit of tethering observed at wall shear stress of $1.0 \mathrm{dyn} / \mathrm{cm}^{2} ;++++$, upper limit of tethering observed at wall shear stress of $2.0 \mathrm{dyn} / \mathrm{cm}^{2}$. Data are representative of $n>5$ independent experiments. activity (Figure 3 and Table 1), possessed the highest percentage of cells with ALDH activity (Deng et al., 2010). CSCs in the MET state may thus maintain or potentially upregulate Eselectin ligands, in contrast to CSCs in EMT. This notion merits further investigation, in that CTCs from breast cancer patients can simultaneously express mesenchymal and stem cell markers in addition to epithelial markers, and not just EMT markers (Aktas et al., 2009; Bonnomet et al., 2010; Armstrong et al., 2011; Kallergi et al., 2011). Moreover, the bone resident chemokine stromal derived factor-1 (SDF-1, Figure 4), known to mediate HSC homing and breast cancer migration through ligation of CXCR4, has been shown to regulate miRNAs in breast cancer cells and stromal cells that control breast cancer cell tumorigenicity and quiescence (Lim et al., 2011; Rhodes et al., 2011a,b). It may only be a matter of time until it is shown that SDF-1 also regulates miRNAs associated with EMT-MET phenotypes of CSCs. Thus, bone microenvironment expression of E-selectin, TGF- $\beta$, and SDF-1 may beckon a certain type of CTC to establish a metastatic colony: a circulating CSC already equipped to infiltrate the bone parenchyma, or else another cell, CSC or otherwise, that will undergo EMT or MET as needed to attach to endothelium, invade, and grow.

Epithelial-to-mesenchymal transition and MET are, by their very names, dynamic transitional regulators of cellular phenotypes and behaviors. Thus far, we have proposed that these pathways modulate E-selectin ligands on breast CTCs and CSCs. However, it is valid to explore the potential roles of E-selectin and its ligands as regulators of EMT and MET. The proper Eselectin ligands expressed at the right time in the right place (e.g., HCELL, Mac-2bp, and/or glycolipids; Burdick et al., 2006; Shirure et al., 2011, 2012; manuscript in preparation) on a breast CTC in the vasculature at the metastatic site) could facilitate EMT- or MET-generated/maintained CSCs in response to microenvironmental cues. E-selectin-primed cells may then effectively establish metastatic colonies. If a CTC encounters a small capillary rather than a larger venule, another possibility arises. Assuming the CTC can sufficiently deform to enter the capillary, which can be tested 
in vitro in a micropipette assay (Figure 2), transit through the capillary with or without E-selectin ligand/E-selectin engagement could also effectively modulate CTC and CSC phenotype. For now, these complex, highly speculative models remain in the theoretical realm, but as separate discoveries are made about CTCs, CSCs, cancer cell mechanical properties, and selectin ligands, comprehensive investigations linking these subjects will become less daunting and perhaps even routine.

Thus, several intriguing theories proposing crosstalk among biochemical and biophysical factors and selectin ligands on CTCs remain to be tested, and are the subject of ongoing collaborative studies in our laboratories. It is anticipated that the results of these investigations will contribute to the fundamental understanding of the cross-regulation of functional selectin ligands with transformative molecular pathways in breast cancer progression, as well as other cancers for which selectins and their ligands are suspected promoters of metastasis.

\section{BEYOND THE HYPOTHESIZED MODEL}

Although this article has been focused on presenting the potential relationships between CSCs, CTCs, and E-selectin ligands in hematogenous distant metastasis, the pathways mediating metastasis in total are far more extensive. Restricting the discussion to the selectins, CTCs may engage P-selectin expressed on blood vascular endothelial cells (Ludwig et al., 2004; Laubli and Borsig, 2010; St Hill, 2012), which is arguably less understood than endothelial E-selectin-mediated pathways. CTCs in the bloodstream may also form multicellular aggregates with platelets and/or leukocytes (Borsig et al., 2002), and the presence of these other cells can alter the manner in which CTCs interact with the vascular endothelium (Kim et al., 1999; Burdick and Konstantopoulos, 2004; Liang and Dong, 2008; Gong et al., 2012). The initial formation of heterotypic aggregates presumably occurs through engagement of P-selectin on platelets or L-selectin on leukocytes with their respective ligands on CTCs (Mannori et al., 1995; Jadhav et al., 2001; McCarty et al., 2002), such as the aforementioned HCELL (Hanley et al., 2005, 2006; Burdick et al., 2006; Barthel et al., 2009), sulfated glycosaminoglycans or proteoglycans (Ma and Geng, 2002; Monzavi-Karbassi et al., 2007; Cooney et al., 2011), or sulfatides (Needham and Schnaar, 1993; Simonis et al., 2010). Perhaps multicellular aggregation induces CSC phenotype(s). This theory warrants further investigation, given the discovery in HB-chips of CTC aggregates indicating prior CTC-leukocyte engagement (Stott et al., 2010), and a recent publication revealing that platelet-cancer cell contact can induce EMT in breast and colon cancer cells (Labelle et al., 2011). Alternatively, completely novel mechanisms of CTC-CSC regulation may be encountered in lymph node metastasis, considering the vastly different biochemical and biophysical environment

\section{REFERENCES}

Abraham, B. K., Fritz, P., McClellan, M., Hauptvogel, P., Athelogou, M., and Brauch, H. (2005). Prevalence of CD44+/CD24-/low cells in breast cancer may not be associated with clinical outcome but may favor distant metastasis.
Clin. Cancer Res. 11, 1154 1159.

Adams, J. M., and Strasser, A. (2008). Is tumor growth sustained by rare cancer stem cells or dominant clones? Cancer Res. 68, 4018-4021.

Aigner, S., Ramos, C. L., HafeziMoghadam, A., Lawrence, M. B.,

of the lymphatic system compared to the blood vasculature (Lund and Swartz, 2010; Swartz and Lund, 2012). Thus, other compelling models of CTC-CSC regulation may be proposed and tested, which could lead to new ways to inhibit cancer metastasis.

\section{CONCLUSION}

A full understanding of how a cancer cell progresses from primary tumor cell to CTC to disseminated tumor cell remains elusive. Although EMT, MET, and stem cell pathways are clearly relevant, their effects relative to selectin ligands (and vice versa) on CTCs remain to be determined. On their directed journey to establish new metastatic colonies, CTCs are subject to the influences of a bevy of biochemical and biophysical stressors that may change their phenotype at specific times and at specific locations. CTCs captured from the blood of cancer patients by CellSearch, CTCor HB-chips, AdnaTest, and other devices reflect only a single temporal data point from which inferences about disease status, treatment strategies, and survival predictions are extrapolated. While this information from blood biopsies is extraordinarily important, some caution is warranted. Molecular markers and phenotypes serving as the basis of capture in these assays have limitations, and information derived from these assays may have further shortcomings in light of CTC dynamism. Therefore, novel CTC capture techniques and therapeutic strategies currently in development must respect the changing epithelial, mesenchymal, CSC-associated, etc., markers and functional phenotypes (e.g., expression of selectin ligands) to be truly meaningful for patients. Ultimately, collective efforts to elucidate the molecular descriptors of CTCs, including selectin ligands and their regulators such as CSC generation/maintenance pathways, will greatly improve the clinical utility of CTCs as diagnostics, prognostics, therapeutic indicators, or therapeutic targets.

\section{ACKNOWLEDGMENTS}

This work was supported by CBET-1106118 (to Monica M. Burdick, Fabian Benencia, David F. J. Tees), CBET-1039869 (to Douglas J. Goetz, Monica M. Burdick, Fabian Benencia, David F. J. Tees), and BES-0547165 (to David F. J. Tees) from the National Science Foundation, 1R15CA161830-01 from the National Institutes of Health (to Monica M. Burdick), and a seed grant from the Ohio Cancer Research Associates (to Monica M. Burdick). For helpful discussions and assistance with manuscript preparation, we wish to thank our graduate students Mr. Grady Carlson, Ms. Tiantian Liu, Mr. Eric Martin, Ms. Ameneh Mohammadalipour, Mr. John O’Brien, Mr. Venktesh Shirure, and Ms. Chengkai Xiong, as well as our undergraduate students Ms. Emily Blaha, Mr. Aaron Burdette, Mr. Chaz Cuckler, Ms. Jacquelyn Hawes, and Mr. Nate Reynolds.

Friederichs, J., Altevogt, P., and Ley, K. (1998). CD24 mediates rolling of breast carcinoma cells on P-selectin. FASEB J. 12, 1241-1251.

Aktas, B., Tewes, M., Fehm, T., Hauch, S., Kimmig, R., and Kasimir-Bauer, S. (2009). Stem cell and epithelialmesenchymal transition markers are frequently overexpressed in circulating tumor cells of metastatic breast cancer patients. Breast Cancer Res. 11, R46.

Al-Hajj, M., Wicha, M. S., BenitoHernandez, A., Morrison, S. J., and Clarke, M. F. (2003). Prospective identification of tumorigenic breast 
cancer cells. Proc. Natl. Acad. Sci. U S A 100, 3983-3988.

Armstrong, A. J., Marengo, M. S. Oltean, S., Kemeny, G., Bitting, R. L., Turnbull, J. D., Herold, C. I., Marcom, P. K., George, D. J., and Garcia-Blanco, M. A. (2011). Circulating tumor cells from patients with advanced prostate and breast cancer display both epithelial and mesenchymal markers. Mol. Cancer Res. 9, 997-1007.

Badve, S., and Nakshatri, H. (2012). Breast-cancer stem cells-beyond semantics. Lancet Oncol. 13, e43-e48.

Balic, M., Lin, H., Young, L., Hawes, D., Giuliano, A., McNamara, G., Datar, R. H., and Cote, R. J. (2006). Most early disseminated cancer cells detected in bone marrow of breast cancer patients have a putative breast cancer stem cell phenotype. Clin. Cancer Res. 12, 5615-5621.

Barthel, S. R., Gavino, J. D., Descheny, L., and Dimitroff, C. J. (2007). Targeting selectins and selectin ligands in inflammation and cancer. Expert Opin. Ther. Targets 11, $1473-$ 1491.

Barthel, S. R., Wiese, G. K., Cho, J., Opperman, M. J., Hays, D. L., Siddiqui, J., Pienta, K. J., Furie, B., and Dimitroff, C. J. (2009). Alpha 1,3 fucosyltransferases are master regulators of prostate cancer cell trafficking. Proc. Natl. Acad. Sci. U.S.A. 106, 19491-19496.

Bausch, A. R., Möller, W., and Sackmann, E. (1999). Measurement of local viscoelasticity and forces in living cells by magnetic tweezers. Biophys. J. 76, 573-579.

Bendas, G., and Borsig, L. (2012). Cancer cell adhesion and metastasis: selectins, integrins, and the inhibitory potential of heparins. Intl. J. Cell Biol. 2012, 676731.

Blick, T., Hugo, H., Widodo, E., Waltham, M., Pinto, C., Mani, S. A., Weinberg, R. A., Neve, R. M., Lenburg, M. E., and Thompson, E. W. (2010). Epithelial mesenchymal transition traits in human breast cancer cell lines parallel the CD44(hi/)CD24 (lo/-) stem cell phenotype in human breast cancer. $J$. Mammary Gland Biol. Neoplasia 15, 235-252.

Bonnet, D., and Dick, J. E. (1997). Human acute myeloid leukemia is organized as a hierarchy that originates from a primitive hematopoietic cell. Nat. Med. 3, 730-737.

Bonnomet, A., Brysse, A., Tachsidis, A., Waltham, M., Thompson, E. W., Polette, M., and Gilles, C. (2010). Epithelial-to-mesenchymal transitions and circulating tumor cells. J. Mammary Gland Biol. Neoplasia 15, 261-273.

Borsig, L., Wong, R., Hynes, R. O., Varki, N. M., and Varki, A. (2002). Synergistic effects of L- and P-selectin in facilitating tumor metastasis can involve non-mucin ligands and implicate leukocytes as enhancers of metastasis. Proc. Natl. Acad. Sci. U.S.A. 99, 2193-2198.

Brown, K. A., Aakre, M. E., Gorska, A. E., Price, J. O., Eltom, S. E., Pietenpol J. A., and Moses, H. L. (2004). Induction by transforming growth factorbetal of epithelial to mesenchymal transition is a rare event in vitro. Breast Cancer Res. 6, R215-R231.

Burdick, M. M., Chu, J. T., Godar, S., and Sackstein, R. (2006). HCELL is the major E- and L-selectin ligand expressed on LS174T colon carcinoma cells. J. Biol. Chem. 281, 13899-13905.

Burdick, M. M., and Konstantopoulos, K. (2004). Platelet-induced enhancement of LS174T colon carcinoma and THP-1 monocytoid cell adhesion to vascular endothelium under flow. Am. J. Physiol. Cell Physiol. 287, C539-C547.

Burdick, M. M., McCaffery, J. M., Kim, Y. S., Bochner, B. S., and Konstantopoulos, K. (2003). Colon carcinoma cell glycolipids, integrins, and other glycoproteins mediate adhesion to HUVECs under flow. Am. J. Physiol. Cell Physiol. 284, C977-C987.

Burdick, M. M., McCarty, O. J., Jadhav, S., and Konstantopoulos, K. (2001). Cell-cell interactions in inflammation and cancer metastasis. IEEE Eng. Med. Biol. Mag. 20, 86-91.

Campbell, L. L., and Polyak, K. (2007). Breast tumor heterogeneity: cancer stem cells or clonal evolution? Cell Cycle 6, 2332-2338.

Chambers, A. F., Schmidt, E. E., MacDonald, I. C., Morris, V. L., and Groom, A. C. (1992). Early steps in hematogenous metastasis of B16F1 melanoma cells in chick embryos studied by high-resolution intravital videomicroscopy. J. Natl. Cancer Inst. 84, 797-803.

Chase, S. D., Magnani, J. L., and Simon, S. I. (2012). E-selectin ligands as mechanosensitive receptors on neutrophils in health and disease. Ann. Biomed. Eng. 40, 849-859.

Choquet, D., Felsenfeld, D. P., and Scheetz, M. P. (1997). Extracellular matrix rigidity causes strengthening of integrin-cytoskeleton linkages. Cell 88, 39-48.

Clay, M. R., Tabor, M., Owen, J. H., Carey, T. E., Bradford, C. R., Wolf, G. T., Wicha, M. S., and Prince,
M. E. (2010). Single-marker identification of head and neck squamous cell carcinoma cancer stem cells with aldehyde dehydrogenase. Head Neck 32, 1195-1201.

Cooney, C. A., Jousheghany, F., YaoBorengasser, A., Phanavanh, B. Gomes, T., Kieber-Emmons, A. M. Siegel, E. R., Suva, L. J., Ferrone, S., Kieber-Emmons, T., and MonzaviKarbassi, B. (2011). Chondroitin sulfates play a major role in breast cancer metastasis: a role for CSPG4 and CHST11 gene expression in forming surface P-selectin ligands in aggressive breast cancer cells. Breast Cancer Res. 13, R58.

Costello, R. T., Mallet, F., Gaugler, B., Sainty, D., Arnoulet, C., Gastaut, J. A., and Olive, D. (2000). Human acute myeloid leukemia CD34+/CD38 - progenitor cells have decreased sensitivity to chemotherapy and Fas-induced apoptosis, reduced immunogenicity, and impaired dendritic cell transformation capacities. Cancer Res. 60, 4403-4411.

Darling, E. M., Topel, M., Zauscher, S., Vail, T. P., and Guilak, F. (2008). Viscoelastic properties of human mesenchymally-derived stem cells and primary osteoblasts, chondrocytes, and adipocytes. J. Biomech. 41, 454-464.

Dawood, S., Broglio, K., Valero, V., Reuben, J., Handy, B., Islam, R., Jackson, S., Hortobagyi, G. N., Fritsche, H., and Cristofanilli, M. (2008). Circulating tumor cells in metastatic breast cancer: From prognostic stratification to modification of the staging system? Cancer 113, 2422-2430.

de Vries, T., Knegtel, R. M., Holmes, E. H., and Macher, B. A. (2001). Fucosyltransferases: Structure/function studies. Glycobiology 11, 119R-128R.

Dembo, M., Torney, D. C., Saxman, K., and Hammer, D. (1988). The reaction-limited kinetics of membrane-to-surface adhesion and detachment. Proc. R. Soc. Lond. B Biol. Sci. 234, 55-83.

Deng, S., Yang, X., Lassus, H., Liang, S., Kaur, S., Ye, Q., Li, C., Wang, L. P., Roby, K. F., Orsulic, S., Connolly, D. C., Zhang, Y., Montone, K., Butzow, R., Coukos, G., and Zhang, L. (2010). Distinct expression levels and patterns of stem cell marker, aldehyde dehydrogenase isoform 1 (ALDH1), in human epithelial cancers. PLoS ONE 5, e10277. doi: 10.1371/journal.pone.0010277

DeSantis, C., Siegel, R., Bandi, P., and Jemal, A. (2011). Breast cancer statistics, 2011. CA Cancer J. Clin. 61, 409-418.
Diehn, M., and Clarke, M. F. (2006). Cancer stem cells and radiotherapy: new insights into tumor radioresistance. J. Natl. Cancer Inst. 98, 1755-1757.

Dimitroff, C. J., Lechpammer, M., Long-Woodward, D., and Kutok, J. L. (2004). Rolling of human bonemetastatic prostate tumor cells on human bone marrow endothelium under shear flow is mediated by Eselectin. Cancer Res. 64, 5261-5269.

Doerschuk, C. M., Beyers, N., Coxson, H. O., Wiggs, B., and Hogg, J. C. (1993). Comparison of neutrophil and capillary diameters and their relation to neutrophil sequestration in the lung. J. Appl. Physiol. 74, 3040-3045.

Dupuy, F., Germot, A., Julien, R., and Maftah, A. (2004). Structure/function study of Lewis alpha3and alpha3/4-fucosyltransferases: The alpha1,4 fucosylation requires an aromatic residue in the acceptorbinding domain. Glycobiology 14, 347-356.

Edbrooke, M. R., Britten, C. J., Kelly, V. A., Martin, S. L., Smithers, N., Winder, A. J., Witham, S. J., and Bird, M. I. (1997). The alpha(13)-fucosyltransferases come of age. Biochem. Soc. Trans. 25, 880-886.

Eshel, R., Zanin, A., Sagi-Assif, O., Meshel, T., Smorodinsky, N. I., Dwir, O., Alon, R., Brakenhoff, R., van Dongen, G., and Witz, I. P. (2000). The GPI-linked Ly-6 antigen E48 regulates expression levels of the FX enzyme and of E-selectin ligands on head and neck squamous carcinoma cells. J. Biol. Chem. 275, 1283312840.

Evans, E. A., and Calderwood, D. A. (2007). Forces and bond dynamics in cell adhesion. Science 316, 1148-1153.

Fehm, T., Becker, S., Duerr-Stoerzer, S., Sotlar, K., Mueller, V., Wallwiener, D., Lane, N., Solomayer, E., and Uhr, J. (2007). Determination of HER2 status using both serum HER2 levels and circulating tumor cells in patients with recurrent breast cancer whose primary tumor was HER2 negative or of unknown HER2 status. Breast Cancer Res. 9, R74.

Fillmore, C. M., and Kuperwasser, C. (2008). Human breast cancer cell lines contain stem-like cells that self-renew, give rise to phenotypically diverse progeny and survive chemotherapy. Breast Cancer Res. 10, R25.

Geng, Y., Marshall, J. R., and King, M. R. (2012). Glycomechanics of the metastatic cascade: Tumor cellendothelial cell interactions in the 
circulation. Ann. Biomed. Eng. 40, 790-805.

Giavazzi, R., Foppolo, M., Dossi, R., and Remuzzi, A. (1993). Rolling and adhesion of human tumor cells on vascular endothelium under physiological flow conditions. J. Clin. Invest. 92, 3038-3044.

Ginestier, C., Hur, M. H., CharafeJauffret, E., Monville, F., Dutcher, J., Brown, M., Jacquemier, J., Viens, P., Kleer, C. G., Liu, S., Schott, A., Hayes, D., Birnbaum, D., Wicha, M. S., and Dontu, G. (2007). ALDH1 is a marker of normal and malignant human mammary stem cells and a predictor of poor clinical outcome. Cell Stem Cell 1, 555-567.

Gong, L., Mi, H. J., Zhu, H., Zhou, X., and Yang, H. (2012). P-selectin-mediated platelet activation promotes adhesion of non-small cell lung carcinoma cells on vascular endothelial cells under flow. Mol. Med. Rep. 5, 935-942.

Graham, S. M., Jorgensen, H. G., Allan, E., Pearson, C., Alcorn, M. J., Richmond, L., and Holyoake, T. L. (2002). Primitive, quiescent, Philadelphiapositive stem cells from patients with chronic myeloid leukemia are insensitive to STI571 in vitro. Blood 99 319-325.

Gupta, P. B., Chaffer, C. L., and Weinberg, R. A. (2009). Cancer stem cells: mirage or reality? Nat. Med. 15, 1010-1012.

Ham, A. S., Goetz, D. J., Klibanov, A. L., and Lawrence, M. B. (2007). Microparticle adhesive dynamics and rolling mediated by selectin-specific antibodies under flow. Biotechnol. Bioeng. 96, 596-607.

Hanley, W. D., Burdick, M. M., Konstantopoulos, K., and Sackstein, R. (2005). CD44 on LS174T colon carcinoma cells possesses E-selectin ligand activity. Cancer Res. 65, 5812-5817.

Hanley, W. D., Napier, S. L., Burdick, M. M., Schnaar, R. L., Sackstein, R., and Konstantopoulos, K. (2006). Variant isoforms of CD44 are P- and Lselectin ligands on colon carcinoma cells. FASEB J. 20, 337-339.

Holtz, M. S., Slovak, M. L., Zhang, F., Sawyers, C. L., Forman, S. J., and Bhatia, R. (2002). Imatinib mesylate (STI571) inhibits growth of primitive malignant progenitors in chronic myelogenous leukemia through reversal of abnormally increased proliferation. Blood 99, 3792-3800.

Hou, H. W., Bhagat, A. A., Chong, A. G., Mao, P., Tan, K. S., Han, J., and Lim, C. T. (2010). Deformability based cell margination - a simple microfluidic design for malaria-infected erythrocyte separation. Lab Chip 10, 2605-2613.

Izumi, Y., Taniuchi, Y., Tsuji, T., Smith

C. W., Nakamori, S., Fidler, I. J., and Irimura, T. (1995). Characterization of human colon carcinoma variant cells selected for sialyl Le ${ }^{\mathrm{x}}$ carbohydrate antigen: liver colonization and adhesion to vascular endothelial cells. Exp. Cell Res. 216, 215-221.

Jadhav, S., Bochner, B. S., and Konstantopoulos, K. (2001). Hydrodynamic shear regulates the kinetics and receptor specificity of polymorphonuclear leukocyte-colon carcinoma cell adhesive interactions. J. Immunol. 167, 5986-5993.

Jones, R. J., Ambinder, R. F., Piantadosi, S., and Santos, G. W. (1991) Evidence of a graft-versus-lymphoma effect associated with allogeneic bone marrow transplantation. Blood 77, 649-653.

Julien, S., Ivetic, A., Grigoriadis, A. QiZe, D., Burford, B., Sproviero, D., Picco, G., Gillett, C., Papp, S L., Schaffer, L., Tutt, A., TaylorPapadimitriou, J., Pinder, S. E., and Burchell, J. M. (2011). Selectin ligand sialyl-Lewis $\mathrm{x}$ antigen drives metastasis of hormone-dependent breast cancers. Cancer Res. 71, 76837693.

Kajiwara, H., Yasuda, M., Kumaki, N., Shibayama, T., and Osamura, Y. (2005). Expression of carbohydrate antigens (SSEA-1, sialyl-Lewis $\mathrm{X}, \mathrm{DU}-\mathrm{PAN}-2$ and CA19-9) and Eselectin in urothelial carcinoma of the renal pelvis, ureter, and urinary bladder. Tokai J. Exp. Clin. Med. 30, 177-182.

Kallergi, G., Papadaki, M. A., Politaki, E., Mavroudis, D., Georgoulias, V., and Agelaki, S. (2011). Epithelial to mesenchymal transition markers expressed in circulating tumour cells of early and metastatic breast cancer patients. Breast Cancer Res. 13, R59.

Kalluri, R., and Weinberg, R. A. (2009). The basics of epithelial-mesenchymal transition. J. Clin. Invest. 119, 1420 1428.

Kannagi, R. (2004). Molecular mechanism for cancer-associated induction of sialyl Lewis X and sialyl Lewis A expression-The Warburg effect revisited. Glycoconj. J. 20, 353-364.

Kannagi, R., Izawa, M., Koike, T. Miyazaki, K., and Kimura, N. (2004) Carbohydrate-mediated cell adhesion in cancer metastasis and angiogenesis. Cancer Sci. 95, 377-384.

Keelan, E. T., Licence, S. T., Peters, A. M., Binns, R. M., and Haskard, D. O. (1994). Characterization of Eselectin expression in vivo with use of a radiolabeled monoclonal antibody. Am. J. Physiol. 266, H278-H290.

Kelly, P. N., Dakic, A., Adams, J. M., Nutt, S. L., and Strasser, A. (2007). Tumor growth need not be driven by rare cancer stem cells. Science $317,337$.

Khatib, A. M., Fallavollita, L., Wancewicz, E. V., Monia, B. P., and Brodt, P. (2002). Inhibition of hepatic endothelial E-selectin expression by C-raf antisense oligonucleotides blocks colorectal carcinoma liver metastasis. Cancer Res. 62, 5393-5398.

Kim, M. Y., Oskarsson, T., Acharyya, S., Nguyen, D. X., Zhang, X. H., Norton, L., and Massague, J. (2009). Tumor self-seeding by circulating cancer cells. Cell 139, 1315-1326.

Kim, Y. C., Park, S. J., and Park, J. K. (2008). Biomechanical analysis of cancerous and normal cells based on bulge generation in a microfluidic device. Analyst 133, 1432-1439.

Kim, Y. J., Borsig, L., Han, H. L., Varki, N. M., and Varki, A. (1999). Distinct selectin ligands on colon carcinoma mucins can mediate pathological interactions among platelets, leukocytes, and endothelium. Am. J. Pathol. 155, 461-472.

Klopocki, A. G., Krop-Watorek, A., Dus, D., and Ugorski, M. (1996). Adhesion of human uroepithelial cells to E-selectin: possible involvement of sialosyl Lewis ${ }^{\mathrm{A}}$-ganglioside. Int. J. Cancer 68, 239-244.

Konstantopoulos, K., and Thomas, S. N. (2009). Cancer cells in transit: the vascular interactions of tumor cells. Annu. Rev. Biomed. Eng. 11, 177-202.

Kryczek, I., Liu, S., Roh, M., Vatan, L., Szeliga, W., Wei, S., Banerjee, M., Mao, Y., Kotarski, J., Wicha, M. S., Liu, R., and Zou, W. (2012). Expression of aldehyde dehydrogenase and CD133 defines ovarian cancer stem cells. Int. J. Cancer 130, 29-39.

Labelle, M., Begum, S., and Hynes, R. O. (2011). Direct signaling between platelets and cancer cells induces an epithelial-mesenchymal-like transition and promotes metastasis. Cancer cell 20, 576-590.

Lafrenie, R. M., Buchanan, M. R. and Orr, F. W. (1993). Adhesion molecules and their role in cancer metastasis. Cell Biophys. 23, 3-89.

Lapidot, T., Sirard, C., Vormoor, J., Murdoch, B., Hoang, T., CaceresCortes, J., Minden, M., Paterson, B., Caligiuri, M. A., and Dick, J. E. (1994). A cell initiating human acute myeloid leukaemia after transplantation into SCID mice. Nature 367, 645-648.
Laubli, H., and Borsig, L. (2010). Selectins promote tumor metastasis. Semin. Cancer Biol. 20, 169-177.

Lee, Y. H., Albig, A. R., Regner, M., Schiemann, B. J., and Schiemann, W. P. (2008). Fibulin-5 initiates epithelial-mesenchymal transition (EMT) and enhances EMT induced by TGF-beta in mammary epithelial cells via a MMP-dependent mechanism. Carcinogenesis 29, 22432251.

Lenferink, A. E., Cantin, C., Nantel, A., Wang, E., Durocher, Y., Banville, M., Paul-Roc, B., Marcil, A., Wilson, M. R., and O'Connor-McCourt, M. D. (2010). Transcriptome profiling of a TGF-beta-induced epithelialto-mesenchymal transition reveals extracellular clusterin as a target for therapeutic antibodies. Oncogene 29, 831-844.

Liang, S., and Dong, C. (2008). Integrin VLA-4 enhances sialyl-Lewisx/anegative melanoma adhesion to and extravasation through the endothelium under low flow conditions. Am. J. Physiol. Cell Physiol. 295, C701-C707.

Lim, P. K., Bliss, S. A., Patel, S. A., Taborga, M., Dave, M. A., Gregory, L. A., Greco, S. J., Bryan, M., Patel, P. S., and Rameshwar, P. (2011). Gap junction-mediated import of microRNA from bone marrow stromal cells can elicit cell cycle quiescence in breast cancer cells. Cancer Res. 71, 1550-1560.

Liotta, L. A. (1987). Biochemical mechanisms of tumor invasion and metastases. Clin. Physiol. Biochem. 5, 190-199.

Liu, S., Clouthier, S. G., and Wicha, M. S. (2012). Role of microRNAs in the regulation of breast cancer stem cells. J. Mammary Gland Biol. Neoplasia 17, 15-21.

Ludwig, R. J., Boehme, B., Podda, M., Henschler, R., Jager, E., Tandi, C., Boehncke, W. H., Zollner, T. M., Kaufmann, R., and Gille, J. (2004). Endothelial P-selectin as a target of heparin action in experimental melanoma lung metastasis. Cancer Res. 64, 2743-2750.

Lund, A. W., and Swartz, M. A. (2010). Role of lymphatic vessels in tumor immunity: passive conduits or active participants? J. Mammary Gland Biol. Neoplasia 15, 341-352.

Ma, Y. Q., and Geng, J. G. (2002). Obligatory requirement of sulfation for P-selectin binding to human salivary gland carcinoma Acc-M cells and breast carcinoma ZR-75-30 cells. J. Immunol. 168, 1690-1696.

Magee, J. A., Piskounova, E., and Morrison, S. J. (2012). Cancer stem cells: 
impact, heterogeneity, and uncertainty. Cancer cell 21, 283-296.

Mani, S. A., Guo, W., Liao, M. J., Eaton, E. N., Ayyanan, A., Zhou, A. Y., Brooks, M., Reinhard, F., Zhang, C. C., Shipitsin, M., Campbell, L. L., Polyak, K., Brisken, C., Yang, J., and Weinberg, R. A. (2008). The epithelial-mesenchymal transition generates cells with properties of stem cells. Cell 133, 704-715.

Mannori, G., Crottet, P., Cecconi, O., Hanasaki, K., Aruffo, A., Nelson, R. M., Varki, A., and Bevilacqua, M. P. (1995). Differential colon cancer cell adhesion to E-, P-, and L-selectin: role of mucin-type glycoproteins. Cancer Res. 55, 4425-4431.

Marshall, B. T., Long, M., Piper, J. W., Yago, T., McEver, R. P., and Zhu, C. (2003). Direct observation of catch bonds involving cell-adhesion molecules. Nature 423, 190-193.

Mason, T. G., Ganesan, K., van Zanten, J. H., Wirtz, D., and Kuo, S. C. (1997). Particle tracking microrheology of complex fluids. Phys. Rev. Lett. 79, 3282-3285.

Mason, T. G., and Weitz, D. A. (1995). Optical measurements of frequencydependent linear viscoelastic moduli of complex fluids. Phys. Rev. Lett. 74, 1250-1253.

Matsuura, N., Narita, T., Hiraiwa, N., Hiraiwa, M., Murai, H., Iwase, T., Funahashi, H., Imai, T., Takagi, H., and Kannagi, R. (1998). Gene expression of fucosyl- and sialyltransferases which synthesize sialyl Lewis ${ }^{\mathrm{x}}$, the carbohydrate ligands for E-selectin, in human breast cancer. Int. J. Oncol. 12, 1157-1164.

Mazo, I. B., Gutierrez-Ramos, J. C., Frenette, P. S., Hynes, R. O., Wagner, D. D., and von Andrian, U. H. (1998). Hematopoietic progenitor cell rolling in bone marrow microvessels: Parallel contributions by endothelial selectins and vascular cell adhesion molecule 1. J. Exp. Med. 188, 465-474.

McCarty, O. J., Jadhav, S., Burdick, M. M., Bell, W. R., and Konstantopoulos, K. (2002). Fluid shear regulates the kinetics and molecular mechanisms of activation-dependent platelet binding to colon carcinoma cells. Biophys. J. 83, 836-848.

McEver, R. P., and Zhu, C. (2007). A catch to integrin activation. Nat. Immunol. 8, 1035-1037.

Minn, A. J., Kang, Y., Serganova, I., Gupta, G. P., Giri, D. D., Doubrovin, M., Ponomarev, V., Gerald, W. L., Blasberg, R., and Massague, J. (2005). Distinct organ-specific metastatic potential of individual breast cancer cells and primary tumors. J. Clin. Invest. 115, 44-55.

Monzavi-Karbassi, B., Stanley, J. S., Hennings, L., Jousheghany, F., Artaud, C., Shaaf, S., and KieberEmmons, T. (2007). Chondroitin sulfate glycosaminoglycans as major $\mathrm{P}$ selectin ligands on metastatic breast cancer cell lines. Int. J. Cancer 120, 1179-1191.

Moore, M. A. (2001). The role of chemoattraction in cancer metastases. Bioessays 23, 674-676.

Morel, A. P., Lievre, M., Thomas, C., Hinkal, G., Ansieau, S., and Puisieux, A. (2008). Generation of breast cancer stem cells through epithelial-mesenchymal transition. PLoS ONE 3, e2888. doi: 10.1371/ journal.pone.0002888

Mostert, B., Sleijfer, S., Foekens, J. A., and Gratama, J. W. (2009). Circulating tumor cells (CTCs): detection methods and their clinical relevance in breast cancer. Cancer Treat. Rev. 35, 463-474.

Nagrath, S., Sequist, L. V., Maheswaran, S., Bell, D. W., Irimia, D., Ulkus, L. Smith, M. R., Kwak, E. L., Digumarthy, S., Muzikansky, A., Ryan, P., Balis, U. J., Tompkins, R. G., Haber, D. A., and Toner, M. (2007). Isolation of rare circulating tumour cells in cancer patients by microchip technology. Nature 450, 12351239.

Narita, T., Kawasaki-Kimura, N., Matsuura, N., Funahashi, H., and Kannagi, R. (1996). Adhesion of human breast cancer cells to vascular endothelium mediated by sialyl Lewis $^{\mathrm{x}} /$ E-selectin. Breast Cancer 3 , 19-23.

Needham, L. K., and Schnaar, R. L. (1993). The HNK-1 reactive sulfoglucuronyl glycolipids are ligands for $\mathrm{L}$-selectin and P-selectin but not Eselectin. Proc. Natl. Acad. Sci. U.S.A. 90, 1359-1363.

Neve, R. M., Chin, K., Fridlyand, J., Yeh, J., Baehner, F. L., Fevr, T., Clark, L., Bayani, N., Coppe, J. P., Tong, F., Speed, T., Spellman, P. T., DeVries, S., Lapuk, A., Wang, N. J., Kuo, W. L., Stilwell, J. L., Pinkel, D., Albertson, D. G., Waldman, F. M., McCormick, F., Dickson, R. B., Johnson, M. D., Lippman, M., Ethier, S., Gazdar, A., and Gray, J. W. (2006). A collection of breast cancer cell lines for the study of functionally distinct cancer subtypes. Cancer Cell 10, 515-527.

Oakey, J., Applegate, R. W., Jr., Arellano, E., Di Carlo, D., Graves, S. W., and Toner, M. (2010). Particle focusing in staged inertial microfluidic devices for flow cytometry. Anal. Chem. 82, 3862-3867.
Onder, T. T., Gupta, P. B., Mani, S. A., Yang, J., Lander, E. S., and Weinberg, R. A. (2008). Loss of E-cadherin promotes metastasis via multiple downstream transcriptional pathways. Cancer Res. 68, 36453654.

Oravecz-Wilson, K. I., Philips, S. T., Yilmaz, O. H., Ames, H. M., Li, L., Crawford, B. D., Gauvin, A. M., Lucas, P. C., Sitwala, K., Downing, J. R., Morrison, S. J., and Ross, T. S. (2009). Persistence of leukemia-initiating cells in a conditional knockin model of an imatinib-responsive myeloproliferative disorder. Cancer cell 16, 137-148.

Parekkadan, B., and Milwid, J. M. (2010). Mesenchymal stem cells as therapeutics. Annu. Rev. Biomed. Eng. 12, 87-117.

Phillips, T. M., McBride, W. H., and Pajonk, F. (2006). The response of CD24(-/low)/CD44+ breast cancerinitiating cells to radiation. J. Natl. Cancer Inst. 98, 1777-1785.

Ponti, D., Costa, A., Zaffaroni, N., Pratesi, G., Petrangolini, G., Coradini, D., Pilotti, S., Pierotti, M. A., and Daidone, M. G. (2005). Isolation and in vitro propagation of tumorigenic breast cancer cells with stem/progenitor cell properties. Cancer Res. 65, 5506-5511.

Porada, C. D., Zanjani, E. D., and Almeida-Porad, G. (2006). Adult mesenchymal stem cells: a pluripotent population with multiple applications. Curr. Stem Cell Res. Ther. 1, 365-369.

Pountos, I., Corscadden, D., Emery, P., and Giannoudis, P. V. (2007). Mesenchymal stem cell tissue engineering: techniques for isolation, expansion and application. Injury 38(Suppl. 4), S23-S33.

Reim, F., Dombrowski, Y., Ritter, C. Buttmann, M., Hausler, S., Ossadnik, M., Krockenberger, M., Beier, D., Beier, C. P., Dietl, J., Becker, J. C. Honig, A., and Wischhusen, J. (2009). Immunoselection of breast and ovarian cancer cells with trastuzumab and natural killer cells: selective escape of $\mathrm{CD} 44^{\text {high }} / \mathrm{CD} 24^{\text {low }} / \mathrm{HER} 2^{\text {low }}$ breast cancer stem cells. Cancer Res. 69, 8058-8066.

Renkonen, J., Paavonen, T., and Renkonen, R. (1997). Endothelial and epithelial expression of sialyl Lewis(x) and sialyl Lewis(a) in lesions of breast carcinoma. Int. J. Cancer 74 296-300.

Rhodes, L. V., Bratton, M. R., Zhu, Y., Tilghman, S. L., Muir, S. E., Salvo, V. A., Tate, C. R., Elliott, S., Nephew, K. P., Collins-Burow, B. M., and Burow, M. E. (2011a).
Effects of SDF-1-CXCR4 signaling on microRNA expression and tumorigenesis in estrogen receptoralpha (ER-alpha)-positive breast cancer cells. Exp. Cell Res. 317, 25732581.

Rhodes, L. V., Short, S. P., Neel, N. F., Salvo, V. A., Zhu, Y., Elliott, S., Wei, Y., Yu, D., Sun, M., Muir, S. E., Fonseca, J. P., Bratton, M. R., Segar, C., Tilghman, S. L., Sobolik-Delmaire, T., Horton, L. W., Zaja-Milatovic, S., Collins-Burow, B. M., Wadsworth, S., Beckman, B. S., Wood, C. E., Fuqua, S. A., Nephew, K. P., Dent, P., Worthylake, R. A., Curiel, T. J., Hung, M. C., Richmond, A., and Burow, M. E. (2011b). Cytokine receptor CXCR4 mediates estrogenindependent tumorigenesis, metastasis, and resistance to endocrine therapy in human breast cancer. Cancer Res. 71, 603-613.

Riethdorf, S., and Pantel, K. (2008). Disseminated tumor cells in bone marrow and circulating tumor cells in blood of breast cancer patients: current state of detection and characterization. Pathobiology 75, 140-148.

Riethdorf, S., and Pantel, K. (2010). Advancing personalized cancer therapy by detection and characterization of circulating carcinoma cells. Ann. N. Y. Acad. Sci. 1210, 66-77.

Sackstein, R. (2004). The bone marrow is akin to skin: HCELL and the biology of hematopoietic stem cell homing. J. Invest. Dermatol. 122, 1061-1069.

Sackstein, R. (2005). The lymphocyte homing receptors: gatekeepers of the multistep paradigm. Curr. Opin. Hematol. 12, 444-450.

Schweitzer, K. M., Drager, A. M., van der Valk, P., Thijsen, S. F., Zevenbergen, A., Theijsmeijer, A. P., van der Schoot, C. E., and Langenhuijsen, M. M. (1996). Constitutive expression of E-selectin and vascular cell adhesion molecule- 1 on endothelial cells of hematopoietic tissues. Am. J. Pathol. 148, 165-175.

Shirure, V. S., Henson, K. A., Schnaar, R. L., Nimrichter, L., and Burdick, M. M. (2011). Gangliosides expressed on breast cancer cells are E-selectin ligands. Biochem. Biophys. Res. Commun. 18, 423-429.

Shirure, V. S., Reynolds, N. M., and Burdick, M. M. (2012). Mac-2 binding protein is a novel E-selectin ligand expressed by breast cancer cells. PLoS ONE. doi: 10.1371/journal.pone.0044529

Shroff, S. G., Saner, D. R., and Lal, R. (1995). Dynamic micromechanical properties of cultured rat atrial 
myocytes measured by atomic force microscopy. Am. J. Physiol. 269, C286-C292.

Silva, I. A., Bai, S., McLean, K., Yang, K., Griffith, K., Thomas, D., Ginestier, C., Johnston, C., Kueck, A., Reynolds, R. K., Wicha, M. S., and Buckanovich, R. J. (2011). Aldehyde dehydrogenase in combination with CD133 defines angiogenic ovarian cancer stem cells that portend poor patient survival. Cancer Res. 71, 3991-4001.

Simonis, D., Schlesinger, M., Seelandt, C., Borsig, L., and Bendas, G. (2010). Analysis of SM4 sulfatide as a Pselectin ligand using model membranes. Biophys. Chem. 150, 98-104.

Sirghi, L., Kylian, O., Gilliland, D., Ceccone, G., and Rossi, F. (2006). Cleaning and hydrophilization of atomic force microscopy silicon probes. $J$. Phys. Chem. B 110, 25975-25981.

Skorstengaard, K., Vestergaard, E. M., Langkilde, N. C., Christensen, L. L., Wolf, H., and Orntoft, T. F. (1999). Lewis antigen mediated adhesion of freshly removed human bladder tumors to E-selectin. J. Urol. 161, 1316-1323.

Springer, T. A. (1994). Traffic signals for lymphocyte recirculation and leukocyte emigration: the multistep paradigm. Cell 76, 301-314.

Sraj, I., Eggleton, C. D., Jimenez, R., Hoover, E., Squier, J., Chichester, J., and Marr, D. W. (2010). Cell deformation cytometry using diode-bar optical stretchers. J. Biomed. Optics 15, 047010

St Hill, C. A. (2012). Interactions between endothelial selectins and cancer cells regulate metastasis. Front. Biosci. 17, 3233-3251.

Stern, R., Shuster, S., Neudecker, B. A., and Formby, B. (2002). Lactate stimulates fibroblast expression of hyaluronan and CD44: the
Warburg effect revisited. Exp. Cell Res. 276, 24-31.

Stern, R., Shuster, S., Wiley, T. S., and Formby, B. (2001). Hyaluronidase can modulate expression of CD44. Exp. Cell. Res. 266, 167-176.

Stott, S. L., Hsu, C. H., Tsukrov, D. I., Yu, M., Miyamoto, D. T., Waltman, B. A., Rothenberg, S. M., Shah, A. M., Smas, M. E., Korir, G. K., Floyd, F. P., Jr., Gilman, A. J., Lord, J. B., Winokur, D., Springer, S., Irimia, D., Nagrath, S., Sequist, L. V., Lee, R. J., Isselbacher, K. J., Maheswaran, S., Haber, D. A., and Toner, M. (2010). Isolation of circulating tumor cells using a microvortex-generating herringbone-chip. Proc. Natl. Acad. Sci. U.S.A. 107, 18392-18397.

Swartz, M. A., and Lund, A. W. (2012). Lymphatic and interstitial flow in the tumour microenvironment: linking mechanobiology with immunity. Nat. Rev. Cancer 12, 210-219.

Talmadge, J. E., and Fidler, I. J. (2010). AACR centennial series: The biology of cancer metastasis: historical perspective. Cancer Res. 70, 5649-5669.

Tan, S. C., Pan, W. X., Ma, G., Cai, N., Leong, K. W., and Liao, K. (2008). Viscoelastic behaviour of human mesenchymal stem cells. BMC Cell Biol. 9, 40. doi: 10.1186/1471-21219-40

Thomas, S. N., Schnaar, R. L., and Konstantopoulos, K. (2009). Podocalyxin-like protein is an E-/Lselectin ligand on colon carcinoma cells: Comparative biochemical properties of selectin ligands in host and tumor cells. Am. J. Physiol. Cell Physiol. 296, C505-C513.

Thoumine, O., and Ott, A. (1997) Comparison of the mechanical properties of normal and transformed fibroblasts. Biorheology 34, 309-326.
Tozeren, A., Kleinman, H. K. Grant, D. S., Morales, D., Mercurio, A. M., and Byers, S. W. (1995). E-selectin-mediated dynamic interactions of breast- and coloncancer cells with endothelial-cell monolayers. Int. J. Cancer 60, 426-431.

Varki, A. (1997). Selectin ligands: will the real ones please stand up? J. Clin. Invest. 99, 158-162.

Weiss, L., Orr, F. W., and Honn, K. V. (1988). Interactions of cancer cells with the microvasculature during metastasis. FASEB J. 2, 12-21.

Wenzel, C. T., Scher, R. L., and Richtsmeier, W. J. (1995). Adhesion of head and neck squamous cell carcinoma to endothelial cells. The missing links. Arch. Otolaryngol. Head Neck Surg. 121, 12791286.

Yap, B., and Kamm, R. D. (2005). Mechanical deformation of neutrophils into narrow channels induces pseudopod projection and changes in biomechanical properties. J. Appl. Phys. 98, 1930-1939.

Yu, H., Tay, C. Y., Leong, W. S., Tan, S. C., Liao, K., and Tan, L. P. (2010). Mechanical behavior of human mesenchymal stem cells during adipogenic and osteogenic differentiation. Biochem. Biophys. Res. Commun. 393, 150-155.

Yu, M., Stott, S., Toner, M., Maheswaran, S., and Haber, D. A. (2011). Circulating tumor cells: Approaches to isolation and characterization. $J$. Cell. Biol. 192, 373-382.

Zarbock, A., Ley, K., McEver, R. P., and Hidalgo, A. (2011). Leukocyte ligands for endothelial selectins: specialized glycoconjugates that mediate rolling and signaling under flow. Blood 118 6743-6751.
Zeisberg, M., and Neilson, E. G. (2009). Biomarkers for epithelialmesenchymal transitions. J. Clin. Invest. 119, 1429-1437.

Zen, K., Liu, D. Q., Guo, Y. L., Wang, C., Shan, J., Fang, M., Zhang, C. Y., and Liu, Y. (2008). CD44v4 is a major E-selectin ligand that mediates breast cancer cell transendothelial migration. PLoS ONE 3, e1826. doi: 10.1371/journal.pone.0001826

Zhu, C., and McEver, R. P. (2005). Catch bonds: physical models and biological functions. Mol. Cell. Biomech. 2, 91-104.

Conflict of Interest Statement: The authors declare that the research was conducted in the absence of any commercial or financial relationships that could be construed as a potential conflict of interest.

Received: 07 June 2012; paper pending published: 19 June 2012; accepted: 02 August 2012; published online: 20 August 2012.

Citation: Burdick MM, Henson KA, Delgadillo LF, Choi YE, Goetz DJ, Tees DFJ and Benencia $F$ (2012) Expression of Eselectin ligands on circulating tumor cells: cross-regulation with cancer stem cell regulatory pathways? Front. Oncol. 2:103. doi: 10.3389/fonc.2012.00103

This article was submitted to Frontiers in Cancer Molecular Targets and Therapeutics, a specialty of Frontiers in Oncology. Copyright (c) 2012 Burdick, Henson, Delgadillo, Choi, Goetz, Tees and Benencia. This is an open-access article distributed under the terms of the Creative Commons Attribution License, which permits use, distribution and reproduction in other forums, provided the original authors and source are credited and subject to any copyright notices concerning any third-party graphics etc. 